\title{
Greenpeace, Corporations and Deforestation Crimes: A Case study of Hongkong Shanghai Bank Corporation (HSBC) in Indonesia
}

\section{Lalu Puttrawandi Karjaya}

Universitas Mataram, Mataram, Indonesia

putrawandi@unram.ac.id

\section{Rezki Satris}

Universitas AMIKOM Yogyakarta, Yogyakarta, Indonesia

rezki@amikom.ac.id

\section{Suspiati}

Universitas Mataram, Mataram, Indonesia

suspiatiab@gmail.com

Submitted: 06 November 2019; Revised: 23 December 2019; Accepted: 16 March 2020

\begin{abstract}
Abstrak
Sebagai aktor politik, organisasi non-pemerintah memiliki peran penting dalam sektor lingkungan. Artikel ini bertujuan untuk membahas peran Greenpeace dalam mendorong kebijakan non-deforestasi HSBC di Indonesia. Untuk mengatasi deforestasi di Indonesia, Greenpeace mendesak HSBC untuk menghentikan pendanaan dan menerapkan kebijakan "zero deforestation". Dalam melakukan analisis, peneliti menggunakan konsep NGO dan green theory. Konsep NGO digunakan untuk mengklasifikasikan Greenpeace sebagai suatu organisasi dan menganalisis peran organisasi dalam proses pembuatan kebijakan non-deforestasi HSBC. Sedangkan green theory digunakan untuk melihat urgensi masalah deforestasi dan nilai-nilai yang diperjuangkan oleh Greenpeace.

Kata kunci: greenpeace, deforestasi, HSBC, minyak kelapa sawit, Indonesia.
\end{abstract}

\begin{abstract}
As a political actor, non-governmental organizations have an essential role in the environmental sector. This paper aims to discuss the role of Greenpeace in driving HSBC's non-deforestation policy in Indonesia. To address deforestation in Indonesia, Greenpeace is pressing HSBC to stop funding and implement a "zero deforestation" policy. In conducting the analysis, the researcher utilized the concept of NGOs and green theory. The concept of NGOs was used to classify Greenpeace as an organization and analyze the role of the organization in the process of making HSBC's non-deforestation policy. While the green theory was used to see the urgency of the problems of deforestation and the values championed by Greenpeace.
\end{abstract}

Keywords: reenpeace, deforestation, HSBC, palm oil, Indonesia.

\section{INTRODUCTION}

Environmental issues become an essential part of international security issues, and these are caused by several factors. First, focusing on interactions between ecosystems and humanity, the environment is the basis of broader human security and is crucial for the sustainability of people's welfare. Humans depend on the earth's ecosystem and functions, including the function of providing food and clean water, the function of regulating diseases and climate regulation, cultural functions such as spiritual fulfillment and aesthetic pleasure, and supporting functions such as primary production and land formation (Global Environment Facility, 2014). Environmental security is central to national security. 
The second factor, an increasing population causes economic and social activities, where these activities run in a way that threatens the environment (Jakson \& Sorensen, 2014). The third factor, environmental problems have global effects. These global effects are caused by environmental issues that are transboundary or cross-border, causing the environmental damage in a country to affect the surrounding area. Air pollution does not stop at the border, acid rain, threats to the ozone layer occurring in one country will affect other states, and even the world. The fourth factor, environmental issues also concern the exploitation of global resources such as oceans and the atmosphere. Exploitation or environmental degradation activities have a local or national scale and are carried out in many places throughout the world, making it considered as a global problem, for example, erosion and soil degradation, deforestation, water pollution, and so on.

The fifth factor, the process causing excessive exploitation and environmental degradation, is related to broader political and socio-economic processes where these processes are part of the global political economy (Hartati, 2012). The sixth factor, environmental damage correlates with conflict. A comprehensive study found that internal armed conflict during the period 1946-2006 had relations to natural resources. It happened 39\% in the Middle East and North Africa, 44\% in Sub-Saharan Africa, 56\% in South Asia, and 60\% in East Asia and the Pacific. These conflicts are often triggered by the seizure and distribution of natural resources; for example, the right to access and use natural resources that are no longer abundant (Global Environment Facility, 2014). A concrete example of this correlation is disputed between Middle Eastern countries regarding water resources. These disputes are clear evidence of how the scarcity of environmental resources can exacerbate conflicts between countries (Jakson \& Sorensen, 2014).

As an issue playing a central role in global and national security, the protection and management of natural resources to the responsibility for environmental damage is the responsibility of all parties from the local and international scale, both the community and government. But in reality, maintaining the environment is quite difficult. Various challenges faced by all countries with different threats. Indonesia is one country struggling with this issue. Numerous environmental problems thrive in Indonesia, one of which is deforestation.

As a non-governmental organization (NGO) focusing on the environment, Greenpeace has taken part in the deforestation campaign to protect and uncover the facts of Indonesia's forest destruction since 2003. It was done through in-depth studies on sectors vulnerable to deforestation activities, including timber, palm oil, and paper. The target of this organization's campaign is also very broad, not only the producers of these commodities, Greenpeace is also aggressively urging various parties both retail companies, banks, to the government. It aims to support the preservation of Indonesia's forests from various sides.

The explanation above shows that there have been many efforts and contributions made by Greenpeace on environmental issues in Indonesia. In this case, it can be seen that Greenpeace as an NGO, has a strong influence in suppressing other parties. Therefore, in this study, the author is interested in examining the role Greenpeace has in the realization of the "zero deforestation" policy by HSBC. HSBC is one of the ten largest banks in 2016 based in Europe. This bank is the 14th largest public company in the world in 2015 (Greenpeace Indonesia, 2017). HSBC has had sustainability policies covering the forestry and agriculture sectors since 2004, and in 2016 recognized the need to switch to a low-carbon economy. However, in reality, HSBC continues to fund companies and projects in the high carbon sector, including coal and palm oil.

Financial service providers such as HSBC can exert influence through their ability to determine environmental aspects as part of the loan, investment, and other financial services requirements (Kusumaningtyas \& Gelder, 2018) so that this sector is considered capable of making a significant contribution to reduce the rate of deforestation due to oil palm plantations. Greenpeace then began to make efforts in urging the London-based bank to stop funding dirty palm oil companies. At various pressures and considerations, HSBC later issued a policy of "zero deforestation” (Greenpeace Indonesia, 2017). 


\section{LITERATURE REVIEW}

Environmental issues have been popular among academics. The literature on these issues is found in various forms, both books, journals, and other research. In this article, the author used some literature dealing with the role of NGOs in environmental issues. First, a study entitled "The Role and Strategy of Non-Government Organizations (NGOs) in the Political Arena of the Environment" (Ardhian et al., 2016). This research was conducted in 2016 by David Ardhian, Soeryo Adiwibowo, and Ekawati Sri Wahyuni. David et al., explained the role and strategy of NGOs in the political arena of the environment by using cases of forest and land fires in Indonesia.

Forest and land fires are one of the environmental problems that have intensified in Indonesia over the past seventeen years. From the standpoint of political ecology, forest and land fires are not only biophysical issues but also contain political economy and power relations. The inequality of power relations in the case of forest and land fires can be traced from the long history of forest clearing for economic development, which in this case is closely related to the expansion of forest-based industries, which are divided into three waves. The first wave occurred since the 1970s, where the government gave massive permits to timber companies in the Forest Concession Rights (HPH) and Industrial Plantation Forest (HTI) schemes. The second wave is the expansion of oil palm plantations since the 1990s on the islands of Sumatra and Kalimantan. This period was also marked by a project to clear a million hectares of peatland in Central Kalimantan in the 1995-1999 period for agricultural purposes. The third wave is an increase in demand for palm oil products on the global market since 2000 , and palm oil has become the belle of exports for foreign exchange earnings. Indonesia is listed as the largest global palm oil producer in the world, along with Malaysia. Forest and land fires also have political dimensions and implications, where actors such as the government and companies have power and capital. While the community, as the weakest party, must bear the impacts caused by forest and land fires. It was then considered as a gap by other actors, one of which was
$\mathrm{NGOs,} \mathrm{to} \mathrm{play} \mathrm{their} \mathrm{roles,} \mathrm{influences,} \mathrm{and} \mathrm{interests} \mathrm{in} \mathrm{the}$ cases of forest and land fires.

Using a qualitative approach, David et al., stated that each NGO plays a role in accordance with its respective competencies and capacities in encouraging improvements in the forest and land governance. The forms of the role of NGOs include policy advocacy, public campaigns, capacity building and consultation, knowledge management, and implementors in the field. The study then found NGOs' political strategies in responding to forest and land fires. The first is encouraging change directly to the target. It was done in two forms of action, namely: (1) urging the government to issue regulations protecting forests and peatlands; (2) suing companies legally and attacking land-burning companies with public campaigns and opinion formation in the mass media. The second strategy is using an international advocacy network. It aims to raise cases of forest and land fire at the international level. The third political strategy is using market power by influencing markets and consumers to cut off purchases from companies burning forests and land and encouraging companies to comply with environmental and social management standards. The fourth is influencing the flow of capital.

Several NGOs usually develop coalitions intending to influence financial institutions and banks not to fund companies burning land and forests. The fifth is utilizing the support of government elites who NGOs think can provide input on policies in the context of forest and land fire control. Finally, the sixth is raising best practices. It aims to promote approaches and models at the site level, as opposed to government programs unable to address the problems of forest and land fires. The research of David Ardhian et al., is one of the interesting studies. Although the case studies raised are different, this research can be used as a basis for development to assess the role and strategy of Greenpeace as an NGO engaged in the environmental field in the writer's writings.

Second, a study conducted by Kartika Yustika Mandala Putri in 2016 entitled "Greenpeace Diplomacy in Suppressing Amazon Deforestation as a Result of 
Soybean Agriculture" (Mandala, 2016). The study explains the deforestation occurring in Brazil at the time of soybean agriculture. Deforestation in question began with the development of soybean agribusiness in Brazil, which gradually took over the Amazon forest area for a soybean plantation. Until 2012, it was recorded that the land area used as a soybean field was 24 million hectares, and 2.1 million hectares of this total took over the Amazon region. Responding to the problem of deforestation, on June 24, 2006, the soy moratorium was agreed as a voluntary commitment signed by the industry and exporters of the Brazilian Vegetable Oil Industries Association (ABIOVE) and the National Grain Exporters Association (ANEC). Not only voluntarily approved by the private sector, but this initiative was also supported by the Government of Brazil and civil society groups.

The researcher then saw that Greenpeace was an NGO that had successfully driven multinational companies to agree on the moratorium's commitment. Later also described the role of Greenpeace in reducing deforestation, namely as a government competitor, mobilization of public opinion, as well as supervisors and evaluators. Government competition means that Greenpeace appears as a party rivaling the intellectual abilities of the government concerning the case by issuing investigation reports. The mobilization of public opinion is the role of Greenpeace as an NGO leading opinions in the community. Therefore, Greenpeace acts as a supervisor and assessor of the consistency of government policy in the soy moratorium. As for this paper, Kartika Yustika Mandala Putri has a similarity, namely studying the role of Greenpeace in addressing the problem of deforestation. However, there are differences in locations where the writer took place in Indonesia, while Kartika Yustika Mandala Putri took place in Brazil.

Finally, the book "Environmental NGOs in World Politics-Linking the Local and Global" by Thomas Princen and Matthias Finger (Princen \& Finger, 1994). This book discusses the role of NGOs in environmental politics. In a sub-chapter entitled "NGOs: creating a niche in environmental diplomacy", Thomas Princen proposed two approaches in analyzing the process of forming environmental policies, namely top-down and bottom-up. The top-down approach emphasizes traditional diplomacy, where bilateral and multilateral bargaining is the main instruments in achieving national and international objectives. National interest and power distribution are the main determinants in determining outcomes. Major power is an essential player in solving environmental problems. International organizations act as coordinators and implementers of state intentions, while NGOs act as advisors on the sidetrack. Whereas the bottom-up approach emphasizes community organizing, grass-root movements, local participation, and the formation of local decisions. From the explanation above, what distinguishes this research from previous research is the emphasis on Greenpeace in finding HSBC as the largest funder of Indonesian palm oil destroyer companies. Greenpeace then sought to urge HSBC to stop funding and implement a "zero deforestation" policy.

\section{RESEARCH METHOD}

This article employed a descriptive qualitative research method by processing sources from various literature. Greenpeace handling in the analysis of the zero-deforestation study can be seen from various available sources, such as the literature books, journals, newspapers, and others. Therefore, the phenomenon experienced by research subjects can be understood holistically and through descriptions in the form of words and language in specific natural contexts by utilizing various natural methods. Qualitative methods are used to answer descriptive questions aiming to provide an overview of a problem, symptoms, facts, events widely and deeply (Semiawan, 2010). This type of research also prioritizes the process than the product produced. In contrast to quantitative research, the instrument in qualitative researcher is the researchers themselves. Hence, researchers must be able to think and have sufficient knowledge related to the topic under study. 


\section{RESULT AND ANALYSIS DEFORESTATION IN INDONESIA}

Deforestation, clearing, or depletion of forests by humans is one of the biggest problems in land use. This issue is a global focus for having a significant impact on climate change, where deforestation accounts for $15 \%$ of the total carbon emissions released into the atmosphere. This percentage is even more significant than carbon emissions coming from motorcycles, cars, and trucks throughout the world streets (Scientific American). Furthermore, deforestation also impacts on the loss of biodiversity, soil erosion, disruption of the water cycle, and a decline in the quality of life of populations (Bradford, 2018).

At present, deforestation poses a serious threat to global forests. The remaining forest area is only 30-35 million square kilometers or about $25 \%$ of the total land surface (Global Issues Network). It happens all over the world, especially in the tropical rain forest region. Since 1960, more than half of tropical forests have been degraded, and every second more than one hectare of tropical forest has been drastically damaged and degraded. From 2000 to 2009, 32 million hectares of tropical rainforest were cut down and shrinking more than 130,000 square kilometers annually (The International Union of Conservation of Nature).

Indonesia has the most extensive tropical rain forest cover in the world after Brazil and the Democratic Republic of the Congo. The history of Indonesia's forests is the history of deforestation. For a decade, Indonesia has struggled with prolonged deforestation. Since the 1990s, various studies have noted the diminishing condition of Indonesia's forests. Food and Agriculture Organizations (FAO) research in 1990 showed that forest cover in this country had decreased from $74 \%$ to $56 \%$ over $30-40$ years. Public Radio International (PRI) also states that in the last 25 years, Indonesia has lost almost a quarter of its forest area (Beeler \& Kuek, 2016).

Before talking a lot about deforestation happening in Indonesia, it is necessary to determine in advance the definition and method of calculating deforestation itself. It is essential to be done to help in understanding the deforestation rates released by each party. The definition of deforestation has several interpretations. Many parties have their point of view in interpreting deforestation. From the perspective of forestry science, deforestation is interpreted as a situation of loss of forest cover and its attributes that have implications for the loss of the structure and function of the forest itself (Forest Watch Indonesia, 2018). In the 1990 Global Forest Resources Assessment, FAO interpreted deforestation as the clearing of tree formations into the use of non-forest land. This definition refers to the conversion of forest to other land uses or the long-term reduction of tree canopy cover below the minimum threshold of $10 \%$ (Food and Agriculture Organizations, 1990).

Referring to research conducted by FAO, the World Bank recorded an increase in estimated deforestation every year, in the 1970 s by 300,000 ha/year, in 1981 by 600,000 ha/year, and in 1990 by 1,000,000 ha/year (Sunderlin \& Resosudarmo, 1997). The same data were obtained from the results of the Revilla study in 1993, showing that during 1972-1990 Indonesia lost forest cover for an area of $840,000 \mathrm{ha} /$ year or $0.68 \%$ per year. In the $1996-2000$ period, Forest Watch Indonesia recorded a deforestation rate of 2 million hectares per year. In the span of the next 10 years, the deforestation rate reached 1.5 million hectares per year. Deforestation rates tend to vary each year. However, in the period 2009-2011, it was 1.1 million hectares per year.

The Government of Indonesia, through the Ministry of Environment and Forestry (KLHK), has made a definition of deforestation. In the KLHK periodic report, deforestation is defined as a change in land cover conditions from the forests or forested land cover class to the non-forests or non-forested land cover class (Directorate of Inventory and Monitoring of Forest Resources Directorate General of Forestry Planning, Ministry of Forestry, 2012). Forests or forested areas are conditions of land cover in the form of primary dryland forest, secondary dryland forest, primary swamp forest, secondary swamp forest, primary mangrove forest, secondary mangrove forest, and plantation forest.

While non-forest or non-forested area is a form of land cover in the form of shrubs, swamp shrubs, savannahs, plantations, dryland agriculture, mixed shrub agriculture, 
of deforestation has several interpretations. Many parties have their point of view in interpreting deforestation. From the perspective of forestry science, deforestation is interpreted as a situation of loss of forest cover and its attributes that have implications for the loss of the structure and function of the forest itself (Forest Watch Indonesia, 2018). In the 1990 Global Forest Resources Assessment, FAO interpreted deforestation as the clearing of tree formations into the use of non-forest land. This definition refers to the conversion of forest to other land uses or the long-term reduction of tree canopy cover below the minimum threshold of 10\% (Food and Agriculture Organizations, 1990).

Referring to research conducted by FAO, the World Bank recorded an increase in estimated deforestation every year, in the 1970s by $300,000 \mathrm{ha} /$ year, in 1981 by 600,000 ha/year, and in 1990 by 1,000,000 ha/year (Sunderlin \& Resosudarmo, 1997). The same data were obtained from the results of the Revilla study in 1993, showing that during 1972-1990 Indonesia lost forest cover for an area of $840,000 \mathrm{ha} /$ year or $0.68 \%$ per year. In the $1996-2000$ period, Forest Watch Indonesia recorded a deforestation rate of 2 million hectares per year. In the span of the next 10 years, the deforestation rate reached 1.5 million hectares per year. Deforestation rates tend to vary each year. However, in the period 2009-2011, it was 1.1 million hectares per year.

The Government of Indonesia, through the Ministry of Environment and Forestry (KLHK), has made a definition of deforestation. In the KLHK periodic report, deforestation is defined as a change in land cover conditions from the forests or forested land cover class to the non-forests or non-forested land cover class (Directorate of Inventory and Monitoring of Forest Resources Directorate General of Forestry Planning, Ministry of Forestry, 2012). Forests or forested areas are conditions of land cover in the form of primary dryland forest, secondary dryland forest, primary swamp forest, secondary swamp forest, primary mangrove forest, secondary mangrove forest, and plantation forest.

While non-forest or non-forested area is a form of land cover in the form of shrubs, swamp shrubs, savannahs, plantations, dryland agriculture, mixed shrub agriculture, transmigration, rice fields, ponds, open land, mining, settlements, swamps and airport/sea. In addition to the definition stated by KLHK, the Indonesian government also explained the meaning of deforestation in the Forest Reference Emission Level (FREL) compiled for REDD+. The description contained in FREL is somewhat different from that expressed by KLHK, where deforestation in question is the conversion of natural forest cover to plantation forest or non-forested land occurring only once. Not only the definition, but the calculation of deforestation is also different. KLHK adopts a net deforestation approach, whereby gross deforestation is reduced by the results of reforestation efforts (Directorate of Inventory and Monitoring of Forest Resources, Directorate General of Planology, Ministry of Forestry and the Environment, 2014).

Thus, loss of primary and secondary natural forest covers due to plantations at some point, in the end, does not count as deforestation except at the initial stage of land clearing and harvesting. When trees in plantations grow back, it will count as reforestation and will reduce the net deforestation rate. In contrast to KLHK, FREL utilizes a net deforestation approach where changes in natural forest cover (primary or secondary) to plantations within a specified period will be recorded as deforestation in the implementation of REDD+.

Official data released by the Indonesian government both through the Ministry of Environment and Forestry and FREL documents show a fluctuating number, but on average, it has decreased in each period. The Ministry of Forestry in the 2014 Ministry of Forestry (RKTN) Work Plan document states that the rate of deforestation and forest degradation for the period 2009-2011 has declined dramatically. Only 450 thousand hectares are left compared to the period 1998-2002, reaching around 3.5 million hectares. However, this statement contrasts with the findings of Forest Watch Indonesia (FWI), discovering that the trend of deforestation rates remained high in the last four years (2009-2013), given that the government has implemented a moratorium policy on granting new licenses (Forest Watch Indonesia, 2014). The FWI analysis, based on the interpretation of Landsat satellite imagery, shows that Indonesia has lost 4.5 
million hectares of natural forest or has a rate of around 1.13 million hectares per year in the last four years (Forest Watch Indonesia, 2015). Other studies then support the FWI findings. Matt Hansen of the University of Maryland stated that Indonesia lost forest cover of 15.8 million hectares between 2000 and 2012, ranking fifth behind Russia, Brazil, the United States, and Canada in terms of forest loss. In the same period, Margono et al., in their report entitled "Primary Forest Cover in Indonesia Over 2000-2012," stated that the average deforestation in Indonesia in the period 2000-2012 ranged from 0.8 million hectares/year (Forest Watch Indonesia).

The high rate of deforestation and the severity of forest damage occurring in Indonesia made this country always in the spotlight in various deforestation studies. If Matt Hansen puts Indonesia in fifth place in terms of forest loss, in 2015, Indonesia dominated world deforestation by taking second place after Brazil (Keenan et al., 2015).

\section{CAUSES OF DEFORESTATION IN INDONESIA}

Forest destruction and deforestation occurring in Indonesia are often associated with various factors. According to Forest Watch Indonesia, the causes of deforestation can be grouped into two parts, namely the direct causes and indirect causes (underlying causes). The direct cause of forest destruction and deforestation is due to the conversion of natural forests into annual crops, conversion of natural forests to agricultural and plantation land, exploration and exploitation of extractive industries in forest areas (coal, oil and gas, geothermal), forest and land burning, and conversion to transmigration and other infrastructure. While governance weaknesses are identified as other indirect causes driving deforestation in Indonesia (Forest Watch Indonesia). It is also justified by the Indonesian government, as stated by the Ministry of Environment and Forestry in the periodic computation of

\section{Regional Tree Cover Loss by Diver for the Period 2001-2015}

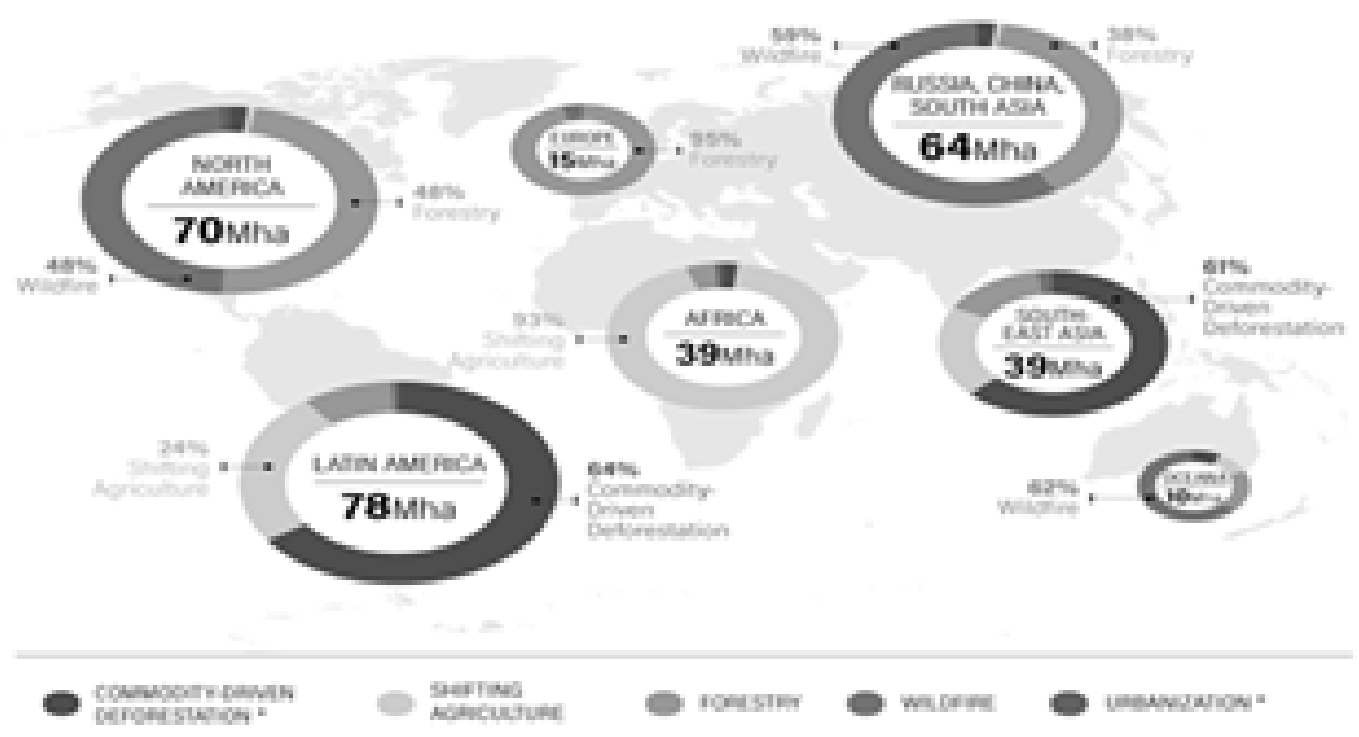

Figure 1. Causes of Loss of Regional Rain Cover 2001-2015

deforestation reports (Directorate of Inventory and Monitoring of Forest Resources Directorate General of Forestry Planning, Ministry of Forestry, 2019). Of the various direct and indirect factors, the conversion of natural forests into plantations is suspected to be the main factor in deforestation. In Southeast Asia alone, clearing of forests to meet commodity demand contributes the most to deforestation by $61 \%$ (Frittz, 2017). clearing of forests to meet commodity demand contributes the most to deforestation by $61 \%$ (Frittz, 2017). 
As is known, Indonesia has three prima donnas in the plantation sector, namely rubber, palm oil, and coffee (Sunderlin \& Resosudarmo). Palm oil then emerged as the dominant actor contributing most of Indonesia's deforestation rate. The plant species of Elaeis guineensis were identified as the biggest drivers of deforestation in the 2009-2011 period, accounting for a quarter of forest loss in Indonesia (Rautner et al., 2013). Even today, palm oil is still a polemic among environmental activists.

Palm oil is the most consumed oil in the world. Apart from being relatively cheap, palm oil is also multifunctional and produces yields up to five times greater than other oil-producing plants, giving the highest yields at the lowest cost per hectare of any oil-producing seed (Rautner et al., 2013). Palm oil is found in a variety of products in many industries, including food, animal feed, cosmetics, pharmaceuticals, chemicals, and is now increasingly found in biofuels (palm oil). In recent decades, palm oil production has experienced a surge in several countries, being in line with the large world market demand for palm oil.

The area of oil palm in large estates has grown twelvefold, from 106,000 hectares in 1967 to approximately 1.3 million hectares in 1995. Palm oil production increased more than ten times from 397,000 tons in 1975 to more than 4 million tons in 1994 (Sunderlin \& Resosudarmo). In 1994 there were
$4,008,062$ tons of oil palm by Indonesia, and large private estates and state plantations managed 1.2 million hectares of oil palm plantations. It was the largest type of large estate crop in Indonesia at that time. Increased production has succeeded in making Indonesia the largest palm oil producer in the world outperforming Malaysia (Indonesia's Largest Palm Oil Producer, Ministry of Industry). Oil palm plantations even beat rubber plantations in terms of area and export value (Ministry of Agriculture, Republic of Indonesia, 2015). According to the 2001 Oil World Annual, global production in 2000 was 21.8 million tons, of which Indonesia produced 7 million tons (32\%).

Being the world's largest palm oil producer is a separate achievement for Indonesia, but it has also become a polemic related to forest and climate sustainability. Most of the expansion of the palm oil industry is done by expanding production land, not by increasing yields, and part of the land-use change associated with the expansion of oil palm plantations is marked by forest loss. From 1990 to 2005, more than $50 \%$ of the expansion of oil palm plantations in Indonesia occurred after the deforestation of tropical forests (Vijay, 2016). Only a few oil palm plantations are free from deforestation. Forest Watch Indonesia revealed in 2014 that oil palm plantations had eliminated around 500 thousand hectares of natural forest in 2009-2013

Table 2. Military Expenditure in USD Million.

\begin{tabular}{ccccccc}
\hline Island & $2006-2009$ & $2009-2011$ & $2011-2012$ & $2012-2013$ & $2013-2014$ & $2015-2016$ \\
& & & & & \\
\hline Sumatra & 419.1 & 214.4 & 387.6 & 191.4 & 228.3 & 99.3 \\
Jawa & 17.7 & 7.4 & 1.1 & 4.3 & -77 & 0 \\
Kalimantan & 332.1 & 186.0 & 304.5 & 453.4 & 134.0 & 364.9 \\
Sulawesi & 20.1 & 19.7 & 2.0 & 45.7 & 17.7 & 85.5 \\
Bali Nusa Tgr & 1.7 & 1.6 & 5.8 & 2.5 & 0.2 & 29.8 \\
Maluku & 6.4 & 11.0 & 6.5 & 6.9 & 2.5 & 32.7 \\
Papua & 35.1 & 10.5 & 20.3 & 23.8 & 22.3 & 17.0 \\
Total & 823.1 & 450.6 & 727.8 & 728.0 & 397.4 & 629.2 \\
\hline
\end{tabular}

Note. Data are accessed from KLHK Deforestation Report. 
(Forest Watch Indonesia). Another study conducted in 2016 by Vijay et al. mentioned that the expansion of oil palm plantations was responsible for $54 \%$ of deforestation in Indonesia between 1989-2013. Of the $91.7 \%$ growth in oil palm plantations, $53.8 \%$ of the land came from deforestation (Vijay, 2016).

Abood in 2015 also indicates the extent to which the expansion of oil palm plantations is associated with forest loss in Indonesia in the decade 2000 to 2010. During this decade, the total area of oil palm harvested in Indonesia increased dramatically from 2 million hectares to 6 million hectares. Using satellite imagery, it is found that 1 million hectares of lowland deforestation has occurred in oil palm concessions, 500 thousand hectares in peat swamps, and Indonesia's forest area has disappeared by almost 2\% (Abood et al., 2015). Carlos presents a higher estimate for the same time. According to Carlos's research, deforestation occurring at least in total was 1.6 million hectares in Kalimantan alone, and 400 thousand hectares of that amount occurred on peatlands (Carlson et al., 2013). It shows that at least $70 \%$ of newly developed oil palm plantations in Kalimantan were cleared at the expense of primary and secondary forests. The periodic deforestation report issued by the Ministry of Environment and Forestry contains deforestation rates for each of the seven significant islands/archipelago in Indonesia. The data can be seen in Table 1 .

Based on the table above, the highest deforestation occurred in Sumatra and Kalimantan. It makes the two islands always in the spotlight. Not only because of the highest deforestation rates compared to other islands, but the fact that Kalimantan and Sumatra are the largest oil palm producing regions and have the most concession areas in Indonesia make these islands popular in Indonesia's deforestation studies. The red report card of Kalimantan and Sumatra is an acknowledgment and tangible proof of oil palm as a driver of deforestation.

\section{ROLE OF GREENPEACE IN THE CREATION OF HSBC'S ZERO DEFORESTATION POLICY}

The exposure of the fact $\mathrm{HSBC}$ as the main financier of the palm oil destroyer company and HSBC's failure to carry out its commitment to protect Indonesia's forests is a picture of how industrial development and investment have encouraged humans to take destructive actions against Indonesia's forests and not go according to ecological principles. It certainly attracts the attention of the environmental organization, Greenpeace, which has been active in advocating green values.

As explained earlier, deforestation is one of the focuses of the Greenpeace forest protection campaign. In its campaign, Greenpeace seeks to correct injustices occurring in forest ecosystems and certain groups of people, such as indigenous groups and local communities. In addition to repairing, this organization also strives to prevent damage and guarantee the right to protect forest ecosystems or what is referred to as environmental justice. Therefore, fighting for the concept of zero-deforestation for the palm oil industry as a form of ecological responsibility of the industry players is one of the main objectives to be achieved by Greenpeace.

The zero-deforestation campaign has been carried out since 2011 (Rahmawati, 2019). Initially, this campaign was aimed at companies that were still involved with oil palm dirty, both companies producing oil palm, processors, and retail companies that still used oil palm. This campaign is considered effective with the adoption of the concept and commitment to zero deforestation as the culmination of the New York Declaration on Forests in September 2014. At the same time, several governments are also committed to halting the rate of natural forest loss by 2030 (Pirard et al., 2018). Following the development of this campaign and coinciding with the disclosure of HSBC's involvement in palm oil deforestation, Greenpeace expanded its campaign targets by starting to target financial institutions (banking). Thus, HSBC is the first banking institution to be the target of this organization's campaign.

The zero-deforestation campaign targeting HSBC begins with the publication of the Dirty Bankers Report by Greenpeace International on January 17, 2017. The report contains HSBC's involvement with six companies destroying forests. After that, Greenpeace released an online petition urging $\mathrm{HSBC}$ to stop funding these companies (Greenpeace, 2019). This petition was signed 
by more than 203,000 people worldwide, including Indonesia. Reports and petitions released by Greenpeace were then responded to by HSBC through their official website on January 17, 2019. In the statement, HSBC insisted that HSBC was not interested in funding to customers involved in illegal operations, land clearing by burning, land transfer in high conservation areas, violence, exploitation of child labor or forced labor, violations of human rights to local communities, such as the principles of consent without coercion and basic information, and operations containing social conflicts.

The campaign carried out by Greenpeace seems to have quite an effect on HSBC customers. After this campaign, Stuart Gulliver, CEO of HSBC, got thousands of emails and phone calls from people questioning HSBC's position. These people are mostly from HSBC customers themselves. HSBC also faced many customers leaving this bank. Not only pressure from the public, but Gulliver was also challenged with questions related to Greenpeace's campaign in front of world leaders and corporate leaders at the World Economic Forum held in Davos (Rahmawati, 2019).

The establishment of HSBC's zero deforestation policy reflects the magnitude of Greenpeace's influence in transforming others. In the process of creating this policy, Greenpeace has a significant role. As an NGO, Greenpeace does play a significant role in every environmental advocacy process. This role can be known from the vision and mission of this organization. However, it should be noted that each case study has different characteristics from one another. In the case of HSBC's zero deforestation policy, the role of Greenpeace can be described as follows.

\section{Role as Knowledge Producers}

Greenpeace is an environmental advocacy organization that is active in providing information to the global community regarding environmental issues. In the case of palm oil deforestation, Greenpeace has a quite different position from the government and the private sector, which are mostly more inclined to defend companies involved in the palm oil industry. Greenpeace emerged with a conflicting analysis and perspective
Greenpeace is an environmental advocacy organization that is active in providing information to the global community regarding environmental issues. In the case of palm oil deforestation, Greenpeace has a quite different position from the government and the private sector, which are mostly more inclined to defend companies involved in the palm oil industry. Greenpeace emerged with a conflicting analysis and perspective related to deforestation caused by oil palm plantations. If so far, the government has tended to provide positive packaged information about oil palm plantations, Greenpeace brings new information from the negative side of the sector.

Greenpeace has been investigating the palm oil industry since 2007. Through years of research and collaboration with various parties, Greenpeace then packages the information and distributes it through its media. HSBC's link in deforestation caused by the palm oil industry is packaged in a report entitled "Dirty Bankers". The report, published by Greenpeace International in January 2017, is the result of data processing compiled based on investigation and research. Greenpeace mapping analysis was carried out using Greenpeace's 'Forest Head' online platform and visual assessment or analysis tools including forest cover and agricultural maps released by KLHK, BPN, and BAPPEDA, a collection of data from the University of Maryland's Global Land Analysis \& Discovery (GLAD) laboratory, NASA. Then the organization analyzed the HSBC fund flow based on the results of Profundo Research \& Advice's study entitled "Tycoon-Controlled Palm Oil Groups in Indonesia”, annual financial reports of related companies, RSPO reports, and Bloomberg licenses.

\section{Role as Watchdog (Superintendent)}

An NGO has a supervisory role monitoring the running of a policy, as does Greenpeace. Before publishing the Dirty Bankers report, Greenpeace first conducted research and investigations on HSBC. In the investigation, Greenpeace examined HSBC's policy in 2014, which apparently was not appropriately implemented. HSBC, which prohibits financing and 
causes deforestation, still provides financial services to companies that do not conflict with its policies.

Greenpeace then conveyed it to the broader community through reports, the media, and the campaigns it carried out. Apart from the Dirty Bankers report and articles released on the official websites of Greenpeace International, Greenpeace Indonesia, and the Greenpeace United Kingdom, Greenpeace also utilizes social media in the form of Facebook, Twitter, and Instagram pages. This submission places Greenpeace in the position of a whistle-blower where Greenpeace reports HSBC to the public. It is a part of building a healthier civil society.

\section{Role as Communicator and Opinion Mobilization}

As an environmental organization that has held broad community trust, Greenpeace seeks to communicate the condition of Indonesia's forests and the impact of the dirty palm oil supply chain to the community. Since 2011, Greenpeace has run a zero deforestation campaign for large companies through various media, especially social media. Another form of communication carried out by Greenpeace is campaigns and peaceful actions done in front of HSBC's offices in several countries. By including an orang-utan costume, Greenpeace seeks to convey the suffering of these animals in habitats that are almost extinct due to the expansion of oil palm plantations.

Thousands of e-mails and telephone calls to protest against HSBC, termination by HSBC customers, and the petition signed by 203,000 people around the world are a tangible form of Greenpeace's success in mobilizing public opinion. The community has become aware, trusted, and concerned about forest preservation and has assumed the need to clean the palm oil supply chain through various sectors, including the banking sector, and considers HSBC to play a significant role in the cleaning. This assumption finally pushed the community to put pressure on HSBC to cut off and review its relationship with the six destructive palm oil companies.

\section{Role as an Innovator}

Not only communicating the desire to related parties, but in this case, Greenpeace also placed itself as the party designing and giving recommendations on green financial rules to HSBC. In addition, Greenpeace also provides recommendations on key principles that should be applied by banking institutions such as HSBC. HSBC considered these recommendations in developing the agricultural zero deforestation policy.

\section{CONCLUSION}

The success of Greenpeace's campaign to encourage $\mathrm{HSBC}$ to launch a zero deforestation policy is an excellent achievement considering HSBC is the largest bank in Europe. Besides being driven by environmental issues that have grown into essential topics for the global community, this success is certainly also supported by several factors, including Greenpeace's credibility as an NGO. Greenpeace's long history in the international world and its independence as an NGO make this organization have quite high credibility in the eyes of the global community. Greenpeace's credibility is the first factor driving the success of its environmental advocacy strategy. Then, it makes Greenpeace as an NGO actor working transnationally to garner participation and support from communities around the world. Moreover, Greenpeace has a good, reliable, and extensive environmental network. This organization has forty offices throughout the world. Furthermore, it also has a good relationship with other environmental NGOs in the domestic and international sphere, allowing for the more accurate and varied exchange of information and data, as well as Greenpeace's advocacy skills. Greenpeace has a deep

\section{REFERENCE}

Abood, S. A., Lee, J. S., Burivalova, Z., Garcia-Ulloa, J., \& Koh, L. P. (2015). Relative Contribution of The Logging Fiber, Oil Palm, and Mining Industries to Forest Loss in Indonesia. Conservation Letters, 8(1), 58-67.

Ardhian, D., Adiwibowo, S., \& Wahyuni, E. S. (2016). Peran dan Strategi Organisasi Non Pemerintah Dalam Arena Politik Lingkungan Hidup. Jurnal Sosiologi Pedesaan, 4(3), 211-215.

Beeler, C., \& Kuek, K. (2016, December 30). Indonesia's Rapidly Disappearing Forest in Four Charts. Retrieved May 27, 2019, from https://www.pri.org/stories/2016-12-30/indone sia-s-rapidly-disappearing-forests-four-charts

Bradford, A. (2018, April 3). Deforestation: Facts, Causes, \& Effects. Retrieved May 23, 2019, from Live Science: https://www.livescience.com/27692-deforestation.html

Carlson, K. M., Curran, L. M., Asner, G. P., Pittman, A. M., Trigg, S. N., \& Adeney, J. M. (2013). Carbon Emission From Forest Conversion by Kalimantan Oil Plantations. Nature Climate 
Change, 3(3), 283-287.

Direktorat Inventaris dan Pemantauan Sumber Daya Hutan Direktorat Jenderal Planalogi Kehutanan Kementerian Kehutanan. (2012). Penghitungan Deforestasi Indonesia Perode 2009-2011. Jakarta: Kementerian Kehutanan.

Forest Watch Indonesia. (2015). Intip Hutan. Bogor: Forest Watch Indonesia.

Forest Watch Indonesia. (2019, January 12). Deforestasi Potret Buruk Tata Kelola Hutan. Retrieved from Forest Watch Indonesia: http://fwi.or.id/publikasi/deforestasi-potret-bu ruk-tata-kelola-hutan/

Forest Watch Indonesia. (2019). Lembar Informasi. Forest Watch Indonesia.

Forest Watch Indonesia. (n.d.). Deforestasi Potret Buruk Tata Kelola Hutan. Retrieved January 12, 2019, from Forest Watch Indonesia: http://fwi.or.id/publikasi/deforestasi-po tret-buruk-tata-kelola-hutan/

Forest Watch Indonesia,. (2018). Deforestasi Tanpa Henti. Bogor: Forest Watch Indonesia.

Frittz, R. (2017, September). A New Study Reveals Global Drivers of Deforestation. Retrieved June 26, 2019, from https://ps mag.com/environment/whats-driving-global-deforestation

Global Environment Facility. (2014). Environmental Security: Dimension and Priorities. Retrieved December 25, 2018, from Global Environment Facility: https://www. the gef.org/sites/default/files/council-meeting-docu ments/EN_GEF.STAP_C.54.Inf_.06_Environmental_Securi ty.pdf

Global Issues Network. (n.d.). Deforestation. Retrieved from Global Issues Network: http://globalissuesnet work.org/learn-about-our-global-issues/deforestation/

Greenpeace. (2008, July 25). Para Pendiri. Retrieved May 18, 2018 , from Greenpeace: https://www.Greenpeace.org/archive-in donesia/about/pendiri-Greenpeace/

Greenpeace. (2008, July 29). Sejarah Greenpeace. Retrieved May 18, 2019, from https://www. Greenpeace.org/archive-indo nesia/about/sejarah-Greenpeace/

Greenpeace. (2013). Melindungi Hutan Indonesia. Retrieved May 18, 2019, from Greenpeace: https://www.Green peace.org/archive-indonesia/campaigns/melindun gi-hutan-alam-terakhir/

Greenpeace. (2017). HSBC Berhenti Mendanai Kerusakan Hutan!. Retrieved from Greenpeace: https://act.Green peace.org/page/5378/peti tion/1? ga =2.230439708.1451030416.1562031652$1484285596.1547972991 \&$ gac $=1.116509300$. 1560921462.CjwKCAiA1ZDiBRAXEiwAIWyNCzHy7Xn_ IM7wAbtURQ6Dr8fgL

Greenpeace. (2017). Tentang Kami. Retrieved May 19, 2019, from Greenpeace: https://www.Greenpeace.org/archive-indone sia/about/sia/about/

Greenpeace. (2019, May 18). FAQ. Retrieved from Greenpeace: https://www.Greenpeace.org/indonesia/faq/

Greenpeace Indonesia. (2017). Bankir Kotor. Amsterdam: Green peace International.

Greenpeace Indonesia. (2017, February 21). Kebijakan Baru Nol Deforestasi HSBC Langkah Maju Keberlanjutan Pendanaan Kelapa Sawit. Retrieved October 20, 2018, from Green peace: http://www.Greenpeace.org/seasia/id/high/press/re
lease/keijakan-nol-deforestasi-HSBC/

Hartati, A. Y. (2012). Global Environmental Regime : Ditengah Paham Antroposentris vs Ekosentris. SPEKTRUM, 12(2), 2. Indonesia Investments. (2016, February 2). Minyak Kelapa Sawit. Retrieved April 23, 2017, from Indonesia Investments: http://www.indonesia-investments.com/id/bisnis/komodi tas/minyak-sawit/item 166?

Jakson, R., \& Sorensen, G. (2014). Pengantar Studi Hubungan Internasional: Teori dan Pendekatan. Yogyakarta: Pustaka Pelajar.

Keenan, R. J., Reams, G. A., Achard, F., de Freitas, J. V., Grainger, A., \& Lindquist, E. (2015). Dynamic of Global Forest Area: Result from the FAO Global Forest Resources Assesment 2015. Forest Ecology and Management, 352, 19.

Kementerian Perindustrian. (2009, December 15). Indonesia Produsen Kelapa Sawit Terbesar. Retrieved January 12, 2019, from Kementerian Perindustrian: http://www.kemen perin.go.id/artikel/1075/Indonesia-Produsen-Kelapa-Saw it-Terbesar/

Kementerian Pertanian Republik Indonesia. (2015). Rencana Strategis Kementerian Pertanian Tahun 2015-2019. Jakarta: Kementerian Pertanian Republik Indonesia.

Kusumaningtyas, R., \& Gelder, J. W. (2018). Mewujudkan Pendanaan yang Bertanggungjawab dan Inklusif di Sektor Kelapa Sawit. Bogor: Center for International Forestry Research (CIFOR).

Mandala, P. K. (2016). Diplomasi Greenpeace dalam Menekan Deforestasi Amazon Akibat Agrikultur Kedelai. Jurnal Hubungan Internasional, ix(1), 116-121.

Pirard, R., Gnych, S., Pacheco, P., \& Lawry, S. (2018, May). Komitmen Nol Deforestasi di Indonesia: Tantangan Tata Kelola. Info Brief No. 216, (p. 3).

Princen, T., \& Finger, M. (1994). Enviromental NGOs in World Politics- Linking The Local and Global. London: Routledge.

Rahmawati, A. (2017, January 18). Terungkap! HSBC Ada di Balik Deforestasi Indonesia. Retrieved June 28, 2019, from Greenpeace: https://www.Greenpeace.org/indonesia/ceri ta/1426/terungkap-hsbc-ada-di-balik-krisis-deforestasi-indo nesia/

Rahmawati, A. (2019, July 10). Juru Kampanye Hutan Greenpeace Indonesia. (L. Karjaya. Interviewer)

Rautner, M., Leggett, M., \& Davis, F. (2013). Buku Kecil Pendorong Besar Deforestasi. Oxford: Global Canopy Programme.

Scientific American. (2012). Deforestation and Its Extreme Effect on Global Warming. Retrieved May 15, 2019, from Scientific American: https://www.scientificamerican.com/ar ticle/deforestation-and-global-warming/

Semiawan, C. R. (2010). Metode Penelitian Kualitatif. Jakarta: Grasindo.

Sunderlin, W., \& Resosudarmo, I. A. (1997). Laju dan Penyebab Deforestasi di Indonesia: Penelaahan Kerancuan dan Penyelesaiannya. CIFOR Occasional Paper, 9(1), 1.

The International Union of Conservation of Nature. (n.d.). Deforestation and Forest Degradation. Retrieved May 15, 2019, from https://www.iucn.org/resources/issues-briefs/de forestation-and-forest-degradation

Vijay, V. (2016). The Impact of Palm Oil on Recent Deforestation and Biodiversity Loss. PLOS ONE, 11(7), 2. 